\title{
BIOLOGICAL ACTIVITY OF EXTRACTS AND ESSENTIAL OILS OF TWO ERYNGIUM (APIACEAE) SPECIES FROM THE BALKAN PENINSULA
}

\author{
Jelena S. Matejić1, Zorica Z. Stojanović-Radić2, Zoran Dj. Krivošej³, Bojan K. Zlatković2, \\ Petar D. Marin ${ }^{4}$, Ana M. Džamićt
}

\begin{abstract}
The present study describes antioxidant and antimicrobial activity of water, methanol, acetone and ethyl acetate extracts from Eryngium maritimum L. from Greece and Eryngium serbicum Pančić, growing wild in Serbia. Also, antimicrobial activity of essential oils from aerial parts was analysed. Spectrophotometric methods were used for measuring of total phenols, total flavonoids, as well as for antioxidant potential, using DPPH and ABTS methods. The total phenolic content in the extracts was determined using Folin-Ciocalteu reagent and their amounts ranged between 7.47 and $121.35 \mathrm{mg} \mathrm{GAE} / \mathrm{g}$. The concentrations of flavonoids in the extracts varied from 8.98 to $48.68 \mathrm{mg} \mathrm{QU} / \mathrm{g}$. Antioxidant activity ranged from 1.247 to 31.19 IC $_{50}(\mathrm{mg} / \mathrm{ml})$ and from 0.109 to $3.36 \mathrm{mg} \mathrm{AA} / \mathrm{g}$ when tested with the DPPH and ABTS reagents, respectively. The antimicrobial activity of the extracts and essential oils was investigated using a micro well-dilution assay against the most common human gastrointestinal pathogenic bacterial strains. The most resistant bacterium was Siteptococcus pyogenes, while Staphylococcus aureus showed high sensitivity in presence of all tested extracts exept on water extract of $\mathrm{E}$. maritimum. Essential oil of $E$. serbicum showed better antimicrobial activity than $E$. maritimum oil. This finding suggests that investigated Eryngium species may be considered as a natural source of antioxidant and antimicrobial agents.
\end{abstract}

Acta Medica Medianae 2019;58(3):24-31.

Key words: Eryngium maritimum, E. serbicum, extracts, essential oils, antioxidant, antimicrobial activity

\footnotetext{
${ }^{1}$ University of Niš, Faculty of Medicine, Department of Physics

and Biology with Human Genetics, Niš, Serbia

${ }^{2}$ University of Niš, Faculty of Science and Mathematics,

Department of Biology and Ecology, Niš, Serbia

3University of Priština, Faculty of Natural Sciences, Department of Biology, Kosovska Mitrovica, Serbia

${ }^{4}$ University of Belgrade, Faculty of Biology, Institute of Botany

and Botanical Garden "Jevremovac", Belgrade, Serbia
}

Contact: Jelena S. Matejić

Blvd dr Zorana Đinđića 81, 18000 Niš, Serbia

E-mail: jelena.matejic@medfak.ni.ac.rs

\section{Introduction}

The genus Eryngium, belonging to the subfamily Saniculoideae of the Apiaceae family, is represented by 317 accepted taxa worldwide, known by thier high content of acetylenes, flavonoids, coumarins and triterpene saponins (1). Among them, several Eryngium species have been used as ornamental plants, condiments (2) or in traditional medicine $(3,4)$.
Eryngium maritimum L. (sea holly) is a perennial plant (30-60 cm high) with mauve flowers growing wild on the sandy beaches of West Europe, Mediterranean basin and Black Sea (5). Young roots and shoots of $E$. maritimum are eaten as a vegetable and young leaves are consumed as a salad in northern Europe and Greece. Candied roots of E. maritimum, have been valued as an aphrodisiac tonic especially in England (6). E. maritimum have also been reported to exhibit different therapeutic uses in folk medicine as diuretic or hypoglycemic (7). E. maritimum was in the past a widely used medicinal herb and in modern phytotherapy it is considered a remedy in renal disorders $(3,8)$. The main secondary metabolites isolated from $E$. maritimum extracts were glycosides of kaempferol, isoquercetin and astragalin (9).

Eryngium serbicum Pančić is a perennial plant growing to a height of $40-75 \mathrm{~cm}$. This species is distributed in Serbia and considered a regional endemic $(10,11)$.

In this work the antioxidant activity of four different extracts for $E$. maritimum and $E$. serbicum is reported. Also, we compared antimicrobial effect of essential oils and extracts from aerial parts of this species. To our knowledge, the comparative biological effect of this two species has not been previously reported. 


\section{Material and methods}

\section{Chemicals}

Organic solvents were purchased from "Zorka pharma" Šabac, Serbia. Gallic acid, 3-tert-butyl-4hydroxyanisole (BHA) and 2,2-dyphenyl-1-picrylhydrazyl (DPPH) were obtained from Sigma Chemicals Co., St Louis, MO, USA. Folin-Ciocalteu phenol reagent was purchased from Merck, Darmstadl, Germany. Sodium carbonate anhydrous $\left(\mathrm{Na}_{2} \mathrm{CO}_{3}\right)$, potassium acetate $\left(\mathrm{C}_{2} \mathrm{H}_{3} \mathrm{KO}_{2}\right)$, potassium peroxidisulphate $\left(\mathrm{K}_{2} \mathrm{O}_{8} \mathrm{~S}_{2}\right)$ and $\mathrm{L}(+)$ - Ascorbic acid (Vitamin $\mathrm{C}$ ) were purchased from AnalaR Normapur, VWR, Geldenaaksebaan, Leuven Belgium. Aluminium nitrate nonahydrate $\left(\mathrm{Al}\left(\mathrm{NO}_{3}\right)_{3} \times 9 \mathrm{H}_{2} \mathrm{O}\right)$ was purchased from Fluka Chemie AG, Buchs, Switzerland. ABTS (2,2'-azino-bis (3-ethylbenzothiazoline-6-sulphonic acid)) and quercetin hydrate were obtained from TCI Europe NV,
Boerenveldsweg, Belgium. All other solvents and chemicals were of analytical grade.

\section{Plant material}

Aerial parts from wild growing species of $E$. maritimum (Glyfada, Corfu - Greece) and E. Serbicum (coast of the Ibar river - Serbia) were collected in July 2015. A voucher specimen (10876, 10877) was deposited in the "Herbarium Moesiacum Niš", University of Niš.

\section{Preparation of plant extracts}

Plant material was air dried in the dark and ground to powder. The aerial plants parts $(10 \mathrm{~g})$ were extracted with $100 \mathrm{ml}$ water $\left(\mathrm{H}_{2} \mathrm{O}\right)$, methanol $(\mathrm{MeOH})$, acetone (Acet) or ethyl acetate (EtOAc).

Table 1. The extracts yield for investigated Eryngium species

\begin{tabular}{||l|c|c|c|c||}
\hline Yield of extract (\%, mg per $\mathbf{g})$ & $\mathbf{H}_{\mathbf{2}} \mathbf{O}$ & MeOH & Acet & EtoAc \\
\hline \hline E. maritimum & 0.945 & 0.958 & 0.336 & 0.382 \\
\hline E. serbicum & 0.993 & 1.043 & 0.275 & 0.186 \\
\hline
\end{tabular}

The mixture was exposed to ultrasound bath for $30 \mathrm{~min}$ and after $24 \mathrm{~h}$ standing in the dark was filtered. $\mathrm{MeOH}, \mathrm{EtOAc}$ and Acet solvents were removed by evaporation under the reduced pressure, at maximum temperature of $40^{\circ} \mathrm{C} . \mathrm{H}_{2} \mathrm{O}$ extract was frozen and later dried by freeze-drying. After evaporation of the solvent the crude extract was subjected to subsequent analysis. Extracts concentration was $2 \mathrm{mg} / \mathrm{ml}$. The extracts yields for $E$. maritimum and $E$. serbicum are presented in Table 1.

\section{Essential oils isolation}

Essential oils were obtained separately by hydro-distillation for $3 \mathrm{~h}$, using a Clevengertype apparatus, from $470 \mathrm{~g}$ of dried aerial parts of $E$. Maritimum and $E$. serbicum. Anhydrous sodium sulfate was used for desiccation of oils. Oils were stored at temperature of $4^{\circ} \mathrm{C}$. The yield of essential oils calculated from dried plant material was $0.094 \%$ and $0.091 \%$, respectively.

\section{Determination of total phenolic content}

The total phenolic content of extracts was determined spectrophotometrically by Folin-Ciocalteu method according to slightly modified procedure of Singleton et al. (1999) (12). Briefly, $300 \mu$ of extracts solution and $1500 \mu$ of $1: 10$ Folin-Ciocalteau reagent were mixed and after 6 minutes in the dark $1200 \mu \mathrm{l}$ of sodium carbonate (7.5\%) was added.
After $2 \mathrm{~h}$ of incubation in the dark at room temperature, the absorbance at $740 \mathrm{~nm}$ was measured. The total phenolic concentration was calculated from a gallic acid (GAE) calibration curve $(10-100 \mathrm{mg} / \mathrm{g})$.

\section{Determination of flavonoid content}

The total flavonoid content was evaluated using aluminium nitrate nonahydrate according to the procedure reported by Woisky and Salatino (1998) with some modifications (13). The sample for determination was prepared by mixing a $600 \mu$ of extracts solution and $2580 \mu \mathrm{l}$ of mixture $\left(80 \% \mathrm{C}_{2} \mathrm{H}_{5} \mathrm{OH}, 10 \%\right.$ $\mathrm{Al}\left(\mathrm{NO}_{3}\right)_{3} \times 9 \mathrm{H}_{2} \mathrm{O}$ and $\left.1 \mathrm{M} \mathrm{C} \mathrm{C}_{2} \mathrm{H}_{3} \mathrm{KO}_{2}\right)$. After $40 \mathrm{~min}$ of incubation at room temperature, the absorbance at $415 \mathrm{~nm}$ was measured. The total flavonoid concentration in extracts was calculated from a quercetin hydrate (Qu) calibration curve (10-100 mg/g).

\section{Evaluation of DPPH scavenging activity}

The antioxidant activity of extracts was evaluated by means of the 2,2-diphenyl-1-picrylhydrazil (DPPH) radical scavenging method. This spectrophotometer assay uses stable radical $\mathrm{DPPH}$ as reagent (14).

Absorbance of remaining DPPH radical was measured on $517 \mathrm{~nm}$ after that time $\left(A_{1}\right)$ on Shimadzu, UV-Visible PC 1650 spectrophotometer. Every concentration was done in triplicate and the same was done with Vitamin $\mathrm{C}$ and $\mathrm{BHA}$, known antioxi- 
dants. Blank probes were done in the same way using $\mathrm{MeOH}$ instead of investigated solution $\left(A_{0}\right)$. The decrease of absorption of DPPH solution is calculated by equation:

Percentage of absorption decrease

(on $517 \mathrm{~nm})=\left(A_{0}-A_{1}\right) \times 100 / A_{0}$

Concentrations which decrease absorption of $\mathrm{DPPH}$ solution for $50 \%\left(\mathrm{IC}_{50}\right)$ were obtained from the curve dependence of absorption of DPPH solution on $517 \mathrm{~nm}$ from concentration for each compound and standard antioxidant.

\section{Evaluation of ABTS radical scavenging activity}

For ABTS radical-scavenging activity, the procedure followed the method of Miller and Rice-Evans (1997) with some modifications (15). The ABTS ${ }^{+}$solution was prepared by mixing $19.2 \mathrm{mg}$ of ABTS with $5 \mathrm{ml}$ of potassium persulfate $(2.46 \mathrm{mM})$. The solution was held at room temperature in the dark for 12-16 $\mathrm{h}$ before use. The ABTS ${ }^{+}$solution $(1 \mathrm{ml})$ was diluted with $100-110 \mathrm{ml} \mathrm{H} \mathrm{H}_{2}$, in order to obtain an absorbance $0.7 \pm 0.02$ at $734 \mathrm{~nm}$. Fresh $\mathrm{ABTS}^{+}$solution was prepared for each analysis. Antioxidant or standard solutions, $75 \mu \mathrm{l}$, were mixed with $3 \mathrm{ml}$ of diluted $\mathrm{ABTS}^{+}$solution and incubated at $30^{\circ} \mathrm{C}$ for $30^{\prime}$. The absorbance at $734 \mathrm{~nm}$ was measured. ABTS radical scavenging activity in different extracts was calculated from the Ascorbic acid calibration curve (0-2 $\mathrm{mg} / \mathrm{g})$.

\section{Antimicrobial activity \\ Microbial cultures}

The antimicrobial activity of the investigated samples was evaluated using laboratory control strains obtained from the American Type Culture Collection: Gram (-) bacteria - Escherichia coli ATCC 8739, Pseudomonas aeruginosa ATCC 9027, Klebsiella pneumoniae ATCC 10031, Proteus mira-bilis ATCC 12453; Gram (+) bacteria: Strepto-coccus pyogenes ATCC 19615, Enterococcus faecalis ATCC 19433, Staphylococcus aureus ATCC 6538, Staphylococcus epidermidis ATCC 12228 and yeast Candida albicans ATCC 24433. Bacterial strains were maintained on Nutrient Agar (NA) at $37^{\circ} \mathrm{C}$ and yeast on Sabouraud Dextrose Agar (SDA) at $30{ }^{\circ} \mathrm{C}$ at the Microbiology Laboratory (Department of Biology, Faculty of Science and Mathematics, University of Niš).

\section{Micro-well Dilution Assay}

Antimicrobial activity was evaluated using a broth microdilution method (16). Overnight cultures (18 h) were used for making cell suspensions standardized to 0.5 McFarland turbidity, as measured on McFarland Densitometer (DEN-1, Biosan). Dimethyl sulfoxide $(100 \%)$ was used for making stock solutions of the prepared plant extracts and essential oils. The solutions of the extracts were further diluted with sterile distilled $\mathrm{H}_{2} \mathrm{O}$ (dilution factor 10 ) in order to achieve $10 \%$ solution of the solvent, confirmed by preliminary experiments as non-harmful to the test microorganisms. These solutions were further serially diluted (the diluting factor 2) with sterile PBS in the concentration range $0.001-30 \mathrm{mg} / \mathrm{ml}$. Temperature of incubation was $37^{\circ} \mathrm{C}$ and period of inoculation was $24 \mathrm{~h}$. Controls included chloramphenicol and nystatin as the positive controls, while wells without inoculum and test substance represented the negative control, including test sterility of the medium. Visual reading of the bacterial growth was performed after the addition of triphenyltetrazolium chloride (TTC, $0.5 \%$ ) aqueous solution. The lowest concentration of the test compound that inhibited growth was represented by red colored medium in the wells and considered the minimal inhibitory concentration (MIC). All experiments were done in triplicate.

\section{Statistical analysis}

All values were done in triplicate and presented as average of those values \pm standard deviation. These results were calculated by using Microsoft Excel $2007^{\circledR}$. The $\mathrm{IC}_{50}$ values obtained in the antioxidant assays were determined by reg-ression equation, including the concentration of samples and the scavenging effect. Software used for analyzing the results was OriginPro 8.0. The results were also analyzed using one-way analysis of variance (ANOVA) followed by Tukey's HSD test ( $p \leq 0.05$ ). This analysis was carried out using the Minitab ${ }^{\circledR} 17$ software.

\section{Results}

\section{Total phenolic content}

The results of the total phenolic content determination of the examined plant extracts are presented in Table 2. The content of total phenols in different extracts, expressed as gallic acid equivalents (GAE), ranged between 7.47 to $121.35 \mathrm{mg}$ $\mathrm{GAE} / \mathrm{g}$. The highest phenolic content was found in Acet extract and the lowest in EtOAc for both species. The values for E. maritimum and E. Serbicum extracts were in the next order:

Acet $>\mathrm{H}_{2} \mathrm{O}>\mathrm{MeOH}>$ EtOAC.

\section{Flavonoid concentrations}

The summary of quantities of flavonoids identified in the tested extracts is shown in Table 2. The concentration of flavonoids in $\mathrm{H}_{2} \mathrm{O}, \mathrm{MeOH}$, Acet and EtOAc extracts of aerial parts $E$. maritimum and $E$. serbicum were determined using spectrophotometric method with aluminium nitrate nonahydrate. The content of flavonoids was expressed in terms of quercetin hydrate equivalents. The concentrations of flavonoids in plant extracts ranged from 8.98 to $48.68 \mathrm{mg} \mathrm{Qu} / \mathrm{g}$. The highest flavonoid content was identified in Acet extracts for both species. The lowest content for E. maritimum was identified in $\mathrm{MeOH}$ extracts, while the lowest content for $E$. serbicum was in $\mathrm{H}_{2} \mathrm{O}$ extract. 


\section{DPPH scavenging activity}

DPPH is a very stable free radical. The effect of an antioxidant on DPPH radical scavenging is due to their hydrogen donating ability or radical scavenging activity. When a solution of DPPH is mixed with that of a substance that can donate a hydrogen atom, then this gives rise to the reduced form diphenylpicrylhydrazine with the loss of its violet color (17).

Free radical scavenging capacities of the tested extracts were measured by DPPH assay and results are shown in Table 2. According to the results obtained, different extracts were found active with $\mathrm{IC}_{50}$ value for extracts between 1.247 to 31.19 $\mathrm{mg} / \mathrm{ml}$ of solution. $\mathrm{IC}_{50}$ values of the synthetic anti- oxidant BHA $0.093 \mathrm{mg} / \mathrm{ml}$ and ascorbic acid 0.054 $\mathrm{mg} / \mathrm{ml}$ were determined in parallel experiments. A lower IC $_{50}$ value indicates higher antioxidant activity. $\mathrm{H}_{2} \mathrm{O}$ extract of aerial parts from $E$. maritimum and $E$. serbicum possessed the strongest antioxidant activity compared to others. For both species, EtOAc extracts showed the lowest activity.

\section{ABTS scavenging activity}

The results from the ABTS assay are shown in Table 2. The amount ranged from 0.109 to $3.36 \mathrm{mg}$ $A A / g$. The higher ABTS values present the stronger antioxidant activity. The highest content was identified in $\mathrm{H}_{2} \mathrm{O}$ extract and the lowest in EtOAc extract for both species.

Table 2. Comparative analysis of TPC, TFC, ABTS and DPPH tests between extracts from two Eryngium species

\begin{tabular}{|c|c|c|c|c|}
\hline Antioxidant activity & $\begin{array}{c}\text { TPC } \\
(\mathrm{mg} \mathrm{GAE} / \mathrm{g})\end{array}$ & $\begin{array}{c}\text { TFC } \\
(\mathrm{mg} \mathrm{Qu/g)}\end{array}$ & $\begin{array}{c}\text { ABTS } \\
(\mathrm{mg} \mathrm{AA} / \mathrm{g})\end{array}$ & $\begin{array}{c}\text { DPPH IC } \\
(\mathrm{mg} / \mathrm{ml})\end{array}$ \\
\hline E. maritimum $\left(\mathrm{H}_{2} \mathrm{O}\right)$ & $50.82 \pm 0.008^{d}$ & $9.11 \pm 0.004^{\mathrm{e}}$ & $1.84 \pm 0.023^{c}$ & $2.82 \pm 0.033^{e}$ \\
\hline E. maritimum $(\mathrm{MeOH})$ & $49.01 \pm 0.016^{d}$ & $8.98 \pm 0.007^{e}$ & $1.058 \pm 0.026^{\mathrm{b}}$ & $4.82 \pm 0.012^{d}$ \\
\hline E. maritimum (Acet) & $77.08 \pm 0.138^{\mathrm{bc}}$ & $48.68 \pm 0.026^{\mathrm{a}}$ & $0.769 \pm 0.045^{b}$ & $12.52 \pm 0.033^{b}$ \\
\hline E. maritimum (EtOAc) & $7.47 \pm 0.005^{f}$ & $17.55 \pm 0.014^{\mathrm{d}}$ & $0.109 \pm 0.003^{\mathrm{a}}$ & $31.19 \pm 0.051^{\mathrm{a}}$ \\
\hline E. serbicum $\left(\mathrm{H}_{2} \mathrm{O}\right)$ & $90.1 \pm 0.004^{b}$ & $17.49 \pm 0.004^{d}$ & $3.36 \pm 0.007^{\mathrm{e}}$ & $1.247 \pm 0.005^{\mathrm{h}}$ \\
\hline E. serbicum $(\mathrm{MeOH})$ & $71.41 \pm 0.005^{c}$ & $18.08 \pm 0.002^{\mathrm{d}}$ & $2.34 \pm 0.023^{d}$ & $2.062 \pm 0.023^{f}$ \\
\hline E. serbicum (Acet) & $121.35 \pm 0.01^{\mathrm{a}}$ & $37.18 \pm 0.001^{\mathrm{b}}$ & $2.44 \pm 0.011^{\mathrm{d}}$ & $1.838 \pm 0.013^{9}$ \\
\hline E. serbicum (EtOAc) & $23.056 \pm 0.003^{\mathrm{e}}$ & $28.964 \pm 0.003^{c}$ & $0.544 \pm 0.006^{\mathrm{e}}$ & $10.376 \pm 0.03^{c}$ \\
\hline $\mathrm{BHA}$ & $63.31 \pm 0.001$ & / & $2.66 \pm 0.005$ & $0.093 \pm 0.018$ \\
\hline Ascorbic Acid & $40.91 \pm 0.002$ & / & / & $0.054 \pm 0.002$ \\
\hline
\end{tabular}

Each value in the table was obtained by calculating the average of three analyses \pm standard deviation. Different letters above bars indicate statistically significant differences only among the treatments performed for each assay according to the Tukey test $(p \leq 0.05)$

\section{Antimicrobial activity}

Results obtained for the extract's antimicrobial activity are presented in Table 3. Two antimicrobial commercial agents, namely Chloramphenicol (antibacterial) and Nystatin (antifungal) were used as references for comparison of the investigated extract's activities. Essential oils of the two Eryngium species showed activity at concentrations ranging from $<0.001-15 \mathrm{mg} / \mathrm{ml}$, while the solvent extract's activities ranged from $0.15-30 \mathrm{mg} / \mathrm{ml}$. In the case of the two essential oils, the one isolated from $E$. serbicum plant material showed significantly higher antimicrobial potential (inhibition from $<0.001->2.5 \mathrm{mg} / \mathrm{ml}$ ) in comparison to the oil isolated from $E$. maritimum (3.75-15 $\mathrm{mg} / \mathrm{ml})$. The menti-oned essential oil showed very intensive inhibitory activity, exhibited against all tested microbial strains with the exception of $S$. pyogenes. This activity was especially signif- icant against the two Gram negative human pathogenic bacteria ( $K$. pneumoniae and $P$. mirabilis), where it was determined that inhibitory action can be achieved even at concentrations lower than 1 $\mu \mathrm{g} / \mathrm{ml}$, which is close to the activity of chloramphenicol $(0.39 \mu \mathrm{g} / \mathrm{ml})$. On the other hand, E. Maritimum essential oil showed moderate antimicrobial potential, where the two species ( $K$. pneumoniae and $P$. mirabilis) especially sensitive to the action of the previous oil, as well as $S$. pyogenes demonstrated resistance to the highest tested concentration of this oil.

From the results obtained for the tested solvent extracts, once again, it is clearly visible that $E$. serbicum extracts possessed much higher antimicrobial potential. In the case of E. maritimum extracts, the highest activity has been demonstrated by Acet extract, followed by EtOAc and $\mathrm{MeOH}$ extracts, while $\mathrm{H}_{2} \mathrm{O}$ extract showed no activity against any of the 
Table 3. Comparative antimicrobial activity of extracts and essential oils from two Eryngium species

\begin{tabular}{|c|c|c|c|c|c|c|c|c|c|}
\hline $\begin{array}{l}\text { Antimicrobial } \\
\text { activity }(\mathrm{mg} / \mathrm{ml})\end{array}$ & $\begin{array}{c}\text { S. } \\
\text { aureus }\end{array}$ & $\begin{array}{c}\text { S. } \\
\text { pyogenes }\end{array}$ & $\begin{array}{c}E . \\
\text { faecalis }\end{array}$ & $\begin{array}{c}\text { S. } \\
\text { epidermidis }\end{array}$ & $\begin{array}{l}E . \\
\text { coli }\end{array}$ & $\begin{array}{c}\text { K. } \\
\text { pneumoniae }\end{array}$ & $\begin{array}{c}P . \\
\text { mirabilis }\end{array}$ & $\begin{array}{c}\text { P. } \\
\text { aeruginosa }\end{array}$ & $\begin{array}{c}\text { C. } \\
\text { albicans }\end{array}$ \\
\hline E. maritimum $\left(\mathrm{H}_{2} \mathrm{O}\right)$ & / & I & I & / & I & I & l & / & I \\
\hline E. maritimum $(\mathrm{MeOH})$ & 7.5 & / & 30 & / & l & / & / & 30 & 30 \\
\hline E. maritimum (Acet) & 7.5 & / & 15 & 3.75 & 15 & / & / & 15 & 7.5 \\
\hline E. maritimum (EtOAc) & 10 & / & 10 & 1.25 & / & / & / & / & 5 \\
\hline E. serbicum $\left(\mathrm{H}_{2} \mathrm{O}\right)$ & 10 & $>10$ & 2.5 & 2.5 & $>10$ & 5 & $>10$ & 10 & $>10$ \\
\hline E. serbicum $(\mathrm{MeOH})$ & 1.25 & 1.25 & 0.31 & 1.25 & 0.15 & 1.25 & 0.62 & 2.5 & 0.31 \\
\hline E. serbicum (EtOAc) & 2.5 & $>2.5$ & $>2.5$ & 2.5 & 1.25 & $>2$ & 1.25 & $>2.5$ & $>2.5$ \\
\hline $\begin{array}{l}\text { E. maritimum } \\
\text { (Essential oil) }\end{array}$ & 7.5 & / & 15 & 3.75 & 15 & / & / & 15 & 15 \\
\hline $\begin{array}{l}\text { E. serbicum } \\
\text { (Essential oil) }\end{array}$ & 0.01 & $>2.5$ & 0.015 & 1.25 & 0.62 & $<0.001$ & $<0.001$ & 0.62 & 0.31 \\
\hline $\begin{array}{l}\text { Chloramphenicol } \\
(\mu \mathrm{g} / \mathrm{ml})\end{array}$ & 0.39 & 0.19 & 0.39 & 0.19 & 0.78 & 0.39 & 0.39 & 0.39 & / \\
\hline Nystatin $(\mu \mathrm{g} / \mathrm{ml})$ & / & I & I & / & I & / & & / & 0.09 \\
\hline
\end{tabular}

tested strains. On the other hand, $\mathrm{H}_{2} \mathrm{O}$ extract of $E$. serbicum showed limited activity, against five out of nine panel strains. EtOAc extract exhibited activity against only four strains, but at lower concentrations $(1.25-2.5 \mathrm{mg} / \mathrm{ml})$, which was similar to the activity of Acet extract ( 6 sensitive strains, MIC $=0.31-2.5$ $\mathrm{mg} / \mathrm{ml}$ ). Among the tested extracts of this species, the $\mathrm{MeOH}$ one showed the highest potential, where all strains showed sensitivity to its action at concentrations $0.15-2.5 \mathrm{mg} / \mathrm{ml}$.

\section{Discussion}

Comparative biological study for E. maritimum and endemic $E$. serbicum is largely unknown. Different solvents such as $\mathrm{H}_{2} \mathrm{O}, \mathrm{MeOH}$, Acet, EtOAc, (ranged from higher polarity to lower polarity) extracts were used for the study of antioxidant activity. Various solvents were used to achieve extraction of active substances with diversity in their polarity. For extraction, the solvent is chosen as a function of the type of required phenol or flavonoid. According to given results, $\mathrm{H}_{2} \mathrm{O}$ extract showed high antioxidant activity while EtOAc extract possessed the lowest antioxidant activity (DPPH, ABTS assays). In comparison of the species, E. serbicum possessed higher percentage of total phenol and flavonoid content and equivalently to those results this species have better antioxidative activity.

In a recent study, Tunisian E. maritimum leaf extracts displayed the strongest $\mathrm{H}_{2} \mathrm{O}_{2}$ scavenging ac- tivity $\left(\mathrm{IC}_{50}=76.83 \mu \mathrm{g} / \mathrm{mL}\right.$ ) and the highest DPPH scavenging activity value $\left(\mathrm{IC}_{50}=47.87 \mu \mathrm{g} / \mathrm{mL}\right.$ ) compared to other extracts. Good relationships were observed between antioxidant activities and the total phenolic and flavonoid contents. Nine bioactive compounds were detected in $E$. maritimum extracts: six phenolic acids (gallic acid, catechin, chlorogenic acid, vanillic acid, caffeic acid and cinnamic acid) and three flavonoids (rutin, quercetin and luteolin) (18). In our study, IC 50 value for all E. maritimum extracts was lower, indicating better antioxidative activity. Radical scavenging activity of E. maritimum $\mathrm{MeOH}$ extract revealing $\mathrm{IC}_{50}=0.28 \mathrm{mg} / \mathrm{ml}$ in the ABTS assay was earlier investigated as well (19).

In previous studies (20), Germacrene-D and three uncommon oxygenated sesquiterpenes: $4 \beta \mathrm{H}$ cadin-9-en-15-al, $4 \beta \mathrm{H}$-cadin-9-en-15-ol and $4 \beta \mathrm{H}$ muurol-9-en-15-al were reported as major component of E. maritimum essential oil from Corsica. The main constituents of the $E$. serbicum essential oil from Serbia were germacrene $D, \beta$-elemene and spathulenol (21). Dominant compounds in essential oils have significant part in biological activity.

Previous studies demonstrated that extracts from leaves and roots of Eryngium species (E. Planum, E. campestre and E. maritimum) showed antibacterial and antifungal activity, expecially against dermatophytes $(22,23)$.

Ethanol extracts of E. planum, E. campestre and $E$. maritimum leaves acted inhibitory in range MIC $=0.4-1.9 \mathrm{mg} / \mathrm{ml}$ on $S$. aureus strain (23). Ethanol extract of the E. maritimum against the same 
bacterium exhibited inhibition of growth at 0.7 $\mathrm{mg} / \mathrm{ml}$, while the same study reported activity of same extract against C. albicans at $1.3 \mathrm{mg} / \mathrm{ml}$. In the present investigation, it has been determined that the extracts showing antimicrobial potential had much lower potential than the ethanol one in the mentioned study. Investigation of Meot-Duros et al. (2008) investigated antimicrobial potential of chloroform (non-polar) and $\mathrm{MeOH}$ (polar) extracts of $E$. Maritimum (19). The results showed much higher activity than those obtained here, where polar fraction (MeOH extract) showed activity only against $P$. aeruginosa at only $1 \mu \mathrm{g} / \mathrm{ml}$. In the same study, chloroform extract inhibited $S$. aureus at $10 \mu \mathrm{g} / \mathrm{ml}$, while it was active at $2 \mu \mathrm{g} / \mathrm{ml}$ against $P$. aeruginosa and considering remaining strains mostly at $100 \mu \mathrm{g} / \mathrm{ml}$. Such low active concentrations can be explained by much lower inoculum size added into the test wells of the microtitre plate in the mentioned study, which was 10000 times lower than our $\left(10^{2}\right.$ and $10^{6}$, respectively). In another study, $\mathrm{MeOH}$ extract, Acet extract, EtOAc fraction and butanol fraction extracted from $E$. maritimum were investigated for antimicrobial activity. The results showed that all of them were active against Listeria monocytogenes, Escherichia coli, Staphylococcus aureus and Bacillus cereus, while $\mathrm{MeOH}$ and butanol extract were the only active against Pseudomonas aeruginosa (24). Due to the different methods of antimicrobial activity determination (disc diffusion method), concentrations cannot be compared between this and the present investigation.
There is no clear selectivity considering cell wall structure of the treated microorganisms (bacteria/fungi; Gram-positive/Gram negative). Among the tested microorganisms, the most resistant was $S$. pyogenes, followed by $K$. pneumoniae and P. mirabilis, while $S$. aureus showed the highest sensiti-vity by being resistant only to the action of the $\mathrm{H}_{2} \mathrm{O} E$. maritimum extract.

\section{Conclusion}

All extracts evaluated from E. maritimum and E. serbicum could be used as protective against oxidative stress based on conducted DPPH and ABTS assays. Essential oil isolated from E. serbicum possesses strong antimicrobial activity. Also, all type of extracts inhibited the growth of tested microorganisms. Polyphenolic compound is responsible for the antioxidant and antimicrobial activity. Regular consumption of secondary metabolites isolated from this two species may provide positive consequences for human health.

\section{Acknowledgements}

The authors are grateful to the Ministry of Education, Science and Technological Development of the Republic of Serbia for financial support (Grant No. 173029).
1. Erdelmeier CAJ, Stiche O. A cyclohexenone and a cyclohexadienone glycoside from Eryngium campestre. Phytochemistry 1986; 25:741-3. [CrossRef]

2. Rama CPP, Sudhakar RC, Raza SH, Dutt CBS. Folklore medicinal plants of North Andaman Islands, India. Fitoterapia 2008; 79:458-64. [CrossRef] [PubMed]

3. Küpeli E, Kartal M, Aslan S, Yesilada E. Comparative evaluation of the anti-inflammatory and antinociceptive activity of Turkish Eryngium species. J Ethnopharmacol 2006; 107:32-7. [CrossRef] [PubMed]

4. Yaniv Z, Dafni A, Friedman J, Palevitch D. Plants used for the treatment of diabetes in Israel. J Ethnopharmacol 1987; 19:145-51. [CrossRef] [PubMed]

5. Coste H. Flore descriptive et illustrée de la France, de la Corse et des contrées limitrophes. Paris: Librairie scientifique et technique Albert Blanchart; 1980.

6. Khoshbakht K, Hammer K, Pistrick K. Eryngium caucasicum Trautv. cultivated as a vegetable in the Elburz
Mountains (Northern Iran). Genet Resour Crop Evol 2007; 54:445-8. [CrossRef]

7. Lisciani R, Fattorusso $E$, Surano V, Cozzolino S, Giannattasio M, Sorrentino L. Anti-inflammatory activity of Eryngium maritimum L. rhizome extracts in intact rats. J Ethnopharmacol 1984; 12:263-70. [CrossRef] [PubMed]

8. Suciu S, Bodoki E. Study of triterpene saponins from Eryngium maritimum L. (Apiaceae). TMJ 2005; 55(5): 348-50.

9. Hiller K, Pohl B, Franke P. Flavonoid spectrum of Eryngium maritinum L. part 35. Components of Saniculoidae. Pharmazie 1981; 36(6):451-2.

10. Chater AO. Genus Eryngium L. In: Tutin TG, Heywood $\mathrm{VH}$, Burges NA, Moore DM, Valentine DH, Walters SM, Webb DA, editors. Flora Europaea 2. London, UK: Cambridge University Press; 1968 p. 320-4. 
11. Stevanović V, Tan K, Iatrou G. Distribution of the endemic Balkan flora on serpentine I. - obligate serpentine endemics. PI Syst Evol 2003; 242:149-70. [CrossRef]

12. Singleton VL, Orthofer R, Lamuela-Raventos RM. Analysis of total phenols and other oxidation substrates and antioxidants by means of Folin-Ciocalteu reagent. Meth Enzymol 1999; 299:152-78. [CrossRef]

13. Woisky R, Salatino A. Analysis of propolis: some parameters and procedures for chemical quality control. J Apic Res 1998; 37:99-105. [CrossRef]

14. Blois MS. Antioxidant determinations by the use of a stable free radical. Nature 1958; 181:1199-200. [CrossRef]

15. Miller N, Rice-Evans C. Factors influencing the antioxidant activity determined by the ABTS radical cation assay. Free Radic Res 1997; 26:195-9. [CrossRef] [PubMed]

16. NCCLS - National Committee for Clinical Laboratory Standards, Performance standards for anti-microbial susceptibility testing: eleventh informational supplement, Document M100-S11, National Committee for Clinical Laboratory Standard, Wayne, PA, USA, 2003.

17. Molyneux $P$. The use of the stable free radical diphenylpicrylhydrazyl (DPPH) for estimating antioxidant acti-vity. Songklanakarin J Sci Technol 2004; 26(2):211-9.
18. Rjeibi I, Saad AB, Ncib S, Souid S. Phenolic composition and antioxidant properties of Eryngium maritimum(sea holly). J Coast Life Med 2017; 5(5):212-5. [CrossRef]

19. Moet-Duros L, Le Floch G, Magne C. Radical scavenging, antioxidant and antimicrobial activities of halophytic species. J Ethnopharmacol 2008; 116(2):258-62. [CrossRef] [PubMed]

20. Darriet F, Bendahou M, Desjobert JM, Costa J, Muselli A. Bicyclo[4.4.0]decane oxygenated sesquiterpenes from Eryngium maritimum essential oil. Planta med 2012; 78:386-9. [CrossRef] [PubMed]

21. Capetanos C, Saroglou V, Marin PD, Simić A, Skaltsa HD. Essential oil analysis of two endemic Eryngium species from Serbia. J Serb Chem Soc 2007; 72 (10): 961-5. [CrossRef]

22. Meot-Duros L, Floch G, Magné C. Radical scavenging, antioxidant and antimicrobial activities of halophytic species. J Ethnopharmacol 2008; 116(2):258-62. [CrossRef] [PubMed]

23. Thiem B, Goślińska O, Kikowska M, Budzianowski J. Antimicrobial activity of three Eryngium L. species (Apiaceae). Herba polonica 2010; 56(4):52-8.

24. Kholkhal W, Ilias F, Bekhechi C, Bekkara FA. Eryngium maritimum: a rich medicinal plant of polyphenols and flavonoids compounds with antioxidant, antibacterial and antifungal activities. Curr Res J Bio Sci 2012; 4(4):437-43. 


\title{
BIOLOŠKA AKTIVNOST EKSTRAKATA I ETARSKIH ULJA DVE VRSTE RODA ERYNGIUM (APIACEAE) SA BALKANSKOG POLUOSTRVA
}

\author{
Jelena S. Matejić1, Zorica Z. Stojanović-Radić2 , Zoran Dj. Krivošej ${ }^{3}$, Bojan K. Zlatković2 \\ Petar D. Marin ${ }^{4}$, Ana M. Džamić ${ }^{4}$
}

\begin{abstract}
${ }^{1}$ Univerzitet u Nišu, Medicinski fakultet, Katedra za fiziku i biologiju sa humanom genetikom, Niš, Srbija
${ }^{2}$ Univerzitet u Nišu, Prirodno-matematički fakultet, Odsek za biologiju i ekologiju, Niš, Srbija

${ }^{3}$ Univerzitet u Prištini, Prirodno-matematički fakultet, Odsek za biologiju, Kosovska Mitrovica, Srbija

"Univerzitet u Beogradu, Biološki fakultet, Institut za botaniku i Botanička bašta "Jevremovac", Beograd, Srbija
\end{abstract}

Kontakt: Jelena S. Matejić

Bulevar dr Zorana Đinđića 81, 18000 Niš, Srbija

E-mail: jelena.matejic@medfak.ni.ac.rs

U ovoj studiji opisana je antioksidativna i antimikrobna aktivnost vodenih, metanolnih, acetonskih i etil-acetatnih ekstrakata dobijenih od vrsta Eryngium maritimum L. iz Grčke i Eryngium serbicum Pančić, samonikle u Srbiji. Takođe, analizirana je antimikrobna aktivnost etarskih ulja izolovanih iz nadzemnih delova ovih vrsta. Spektrofotometrijske metode korišćene su za merenje koncentracije ukupnih fenola, flavonoida, kao i za određivanje antioksidativnog potencijala uzoraka upotrebom DPPH i ABTS metoda. Ukupna količina fenola u ekstraktima određena je korišćenjem Folin-Ciocalteu reagensa, a vrednosti su se kretale u opsegu od $7,47 \mathrm{mg} \mathrm{GAE} / \mathrm{g}$ do $121,35 \mathrm{mg} \mathrm{GAE} / \mathrm{g}$. Koncentracija flavonoida u ekstraktima je bila od $8,98 \mathrm{mg} \mathrm{GAE} / \mathrm{g}$ do $48,68 \mathrm{mg} \mathrm{QU} / \mathrm{g}$. Antiokstidativna aktivnost kretala se u opsegu od 1,247 $\mathrm{IC}_{50}$ do $31,19 \mathrm{IC}_{50}(\mathrm{mg} / \mathrm{ml})$ i od $0,109 \mathrm{mg} \mathrm{VitC} / \mathrm{g}$ do $3,36 \mathrm{mg}$ VitC/g za DPPH test i ABTS test. Antimikrobna aktivnost ekstrakta i etarskih ulja ispitivana je pomoću mikrodilucione metode na patogene gastrointestinalnog trakata. Najotpornija bakterija bila je Streptococcus pyogenes, dok je vrsta Staphylococcus aureus pokazala visoku osetljivost na prisustvo svih testiranih ekstrakta osim u slučaju vodenog ekstrakta E. maritimum. Etarsko ulje vrste $E$. Serbicum pokazalo je bolju antimikrobnu aktivnost u odnosu na ulje izolovano iz vrste $E$. Maritimum.

Na osnovu dobijenih rezultata može se zaključiti da vrste roda Eryngium mogu biti potencijalni prirodni izvori antioksidativnih i antimikrobnih agenasa.

Acta Medica Medianae 2019;58(3):24-31.

Ključne reči: Eryngium maritimum, E. serbicum, ekstrakti, etarska ulja, antioksidativna i antimikrobna aktivnost 